\title{
Clinical indicators for nursing diagnosis Ineffective protection in adolescents with cancer
}

\author{
Indicadores clínicos do diagnóstico de enfermagem Proteção ineficaz em adolescentes com câncer \\ Indicadores clínicos del diagnóstico de enfermería Protección ineficaz en adolescentes con cáncer
}

\author{
Marília Mendes Nunes', Tânia Alteniza Leandro', Marcos Venícios de Oliveira Lopes', Viviane Martins da Silva' \\ ' Universidade Federal do Ceará, Faculty of Pharmacy, Dentistry and Nursing, \\ Postgraduate Program in Nursing. Fortaleza, Ceará, Brazil.
}

How to cite this article:

Nunes MM, Leandro TA, Lopes MVO, Silva VM. Clinical indicators for nursing diagnosis Ineffective protection in adolescents with cancer. Rev Bras Enferm [Internet]. 2017;70(6):1330-6. DOI: http://dx.doi.org/10.1590/0034-7167-2016-0571

\author{
Submission: 11-24-2016 Approval: 02-09-2017
}

\begin{abstract}
Objective: To investigate scientific evidence related to the term protection and clinical indicators and etiologic factors for nursing diagnosis Ineffective protection in adolescents with cancer. Method: Integrative literature review in the databases of Scopus, Web of Science, National Library of Medicine and National Institutes of Health (PubMed) and Cochrane; by intersection of the descriptors protection and childhood cancer, which resulted in seven articles. These were insufficient for a comprehension of the term protection and aspects related to its impairment, therefore it was necessary to include a further three reference books. Results: Five clinical indicators and three etiologic factors associated to Ineffective protection were identified some of which were not cited in NANDA-International. Conclusions: There are clinical and etiologic factors important for the identification of ineffective protection in adolescents with cancer. Descriptors: Nursing Diagnosis; Protection; Immunological System; Cancer; Adolescent.
\end{abstract}

\section{RESUMO}

Objetivo: Investigar as evidências científicas acerca do termo proteção e dos indicadores clínicos e fatores etiológicos do diagnóstico de enfermagem Proteção ineficaz em adolescentes com câncer. Método: Realizou-se uma revisão integrativa nas bases de dados Scopus, Web of Science, National Library of Medicine and National Institutes of Health (PubMed) e Cochrane; por meio do cruzamento dos termos protection and childhood cancer, que resultou em sete artigos. Estes não foram suficientes para a compreensão do termo proteção e dos aspectos associados à sua alteração, sendo necessário incluir três livros. Resultados: Foram identificados cinco indicadores clínicos e três fatores etiológicos associados a uma proteção ineficaz, alguns não citados na NANDA-Internacional. Conclusões: Existem indicadores clínicos e fatores etiológicos que podem ser importantes para identificar uma alteração na proteção de adolescentes com câncer.

Descritores: Diagnóstico de Enfermagem; Proteção; Sistema Imunológico; Neoplasias; Adolescente.

\section{RESUMEN}

Objetivo: Investigar las evidencias científicas acerca del término protección y de los indicadores clínicos y factores etiológicos del diagnóstico de enfermería Protección ineficaz en adolescentes con cáncer. Método: Se realizó una revisión integradora en las bases de datos Scopus, Web of Science, National Library of Medicine andNationallnstitutesof Health (PubMed) y Cochrane; por medio del cruce de los términos protection and childhood cancer, que resultó en siete artículos. Estos no fueron suficientes para la comprensión del término protección y de los aspectos asociados a su alteración, siendo necesario incluir tres libros. Resultados: Fueron identificados cinco indicadores clínicos y tres factores etiológicos asociados a una protección ineficaz, algunos no citados en la NANDA-Internacional. Conclusión: Existen indicadores clínicos y factores etiológicos que pueden ser importantes para identificar una alteración en la protección de adolescentes con cáncer.

Descriptores: Diagnóstico de Enfermería; Protección; Sistema Inmunológico; Neoplasias; Adolescente.

\section{CORRESPONDING AUTHOR Marília Mendes Nunes E-mail: marilia_mn@hotmail.com}




\section{INTRODUCTION}

Cancer represents an important global public health problem ${ }^{(1)}$; in Brazil alone, there were an estimated 596 thousand new cases of the disease in 2016. Of these, approximately 12,600 new cases of cancer in children and adolescents were pediatric tumors ${ }^{(2)}$.

Childhood cancer is the first cause of death due to illness among children and adolescents in Brazil and developed countries $^{(3)}$. In the United States, for example, the rate of cancer incidence increased by $0.6 \%$ per year between 1975 and 2012. In contrast, mortality rates declined steadily from 6.5 (per 100,000 population) in 1970 to 2.4 in 2012, representing a global reduction of $63 \%(65 \% \text { in children and } 60 \% \text { in adolescents })^{(1)}$.

With regard to adolescence, it is highlighted that this is a phase in which profound physical, cognitive, social and emotional changes occur ${ }^{(4)}$, which can lead to modifications in the way of understanding and interacting with the world. From 10 to 14 years of age, growth is accelerated, physical changes and development of sexual characteristics occurs, which may be a source of anxiety for the individual ${ }^{(5)}$. In addition, there is acceleration in the electrical and physiological development of the brain, with duplication of the number of cells and reorganization of the neural networks, which has an impact on the emotional, physical and mental capacity of the adolescent ${ }^{(6)}$.

In the final phase of adolescence (15 to 19 years), cigarettes, alcoholic drinks and other drugs can be abused ${ }^{(5)}$ as an alternative to dealing with adverse situations ${ }^{(7)}$. In addition, adolescents present habits and behavior that can lead to situations of violence and illness. Such vulnerabilities are generated by the social context of these individuals and result from historical processes of exclusion and discrimination (poverty, lack of access to education and low levels of schooling, exploitation of labor and exposure to the various forms of violence $)^{(7)}$.

Adolescents need information for their protection, as well as an appropriate space to experience the various transformations inherent in this phase. Consequently, support from the family, school, community and health services is of major importance.

In this context, diverse clinical situations can occur among adolescents that demand special attention from the health professional, as in the case of childhood cancer. Given that adolescents as a population are exposed to situations of vulnerability, the nurse should be familiar with those clinical indicators that infer a diagnosis of Ineffective Protection. In this study, the terms "clinical indicators" and "defining characteristics" are considered to be synonymous.

According to NANDA-I, the Nursing Diagnosis Ineffective Protection (0043) is defined as a "decrease in the ability to guard self from internal or external threats, such as illness or injury"(8). The defining characteristics proposed for Ineffective Protection include: alteration in clotting, alteration in perspiration, anorexia, chilling, coughing, deficient immunity, disorientation, dyspnea, fatigue, immobility, insomnia, itching, maladaptive stress response, neurosensory impairment, pressure ulcer, restlessness, and weakness. The factors related to this human response are: abnormal blood profile, cancer, extremes of age, immune disorder, inadequate nutrition, pharmaceutical agent, substance abuse and treatment regimen ${ }^{(8)}$.

Understanding the importance of knowing the manifestations and causes of changes in the individual's ability to protect self can contribute to an early identification of this problem by the nurse. Thus, this study aims to investigate the scientific evidence focused on the term protection and clinical indicators and etiological factors of nursing diagnosis ineffective protection in adolescents with cancer.

\section{METHOD}

An integrative review study was carried out based on the following steps: problem formulation (elaboration of the guiding question, keywords and inclusion criteria); search procedures (inclusion of relevant literature on the topic of interest); data evaluation (extraction of relevant information from selected articles); data analysis and interpretation (data integration process); and presentation of the review ${ }^{(9)}$.

For the first step of the review, the following guiding questions were elaborated: How is the term protection addressed in the context of childhood cancer? What are the clinical indicators of ineffective protection? What are the factors that can lead to ineffective protection?

The search for articles was realized by two members of the research team, who later discussed the relevance and inclusion of the articles in the final review. This search was performed in the databases of Scopus, Web of Science, National Library of Medicine and National Institutes of Health (PubMed) and Cochrane, in January and February 2015, using as keywords the terms protection and childhood cancer. At the intersection of the descriptors, we used the Boolean operator AND.

We used the opposite term for nursing diagnosis Ineffective protection to identify its components in the context of childhood cancer, considering that for NANDA-I, the focus of this diagnosis is the word protection. The term ineffective refers to the axis of judgment and is defined as that which does not produce the intended or desired effect ${ }^{(10)}$. Protection was used as a defining term, so that later it was possible to interpret which elements are important to identify changes in an individual's capacity to guard self.

The following inclusion criteria were then applied to refine the search: complete articles and electronically available in Portuguese, English or Spanish that addressed the guiding questions. The search and selection process of the articles was based on the Preferred Reporting Items for Systematic Review and Meta-Analyses (PRISMA), as shown in the flow diagram (Figure 1).

The selection process for the studies was carried out by reading the title, abstracts and, later, the complete article. In this manner, the final selection included seven articles that met the inclusion criteria, three of these from the Scopus database, one from Web of Science, one from Pubmed and two from Cochrane. The articles were then classified according to the level of scientific evidence proposed by Howick et al. ${ }^{(11)}$.

Reading the articles found in the review obtained insufficient results that contributed to an understanding of the term protection and its component elements, possibly due to the physiological condition associated with protection. Thus, it was necessary to consult additional literature, by including reference books, since these provide a description of the physiological processes that play a role in an individual's process of protection. 


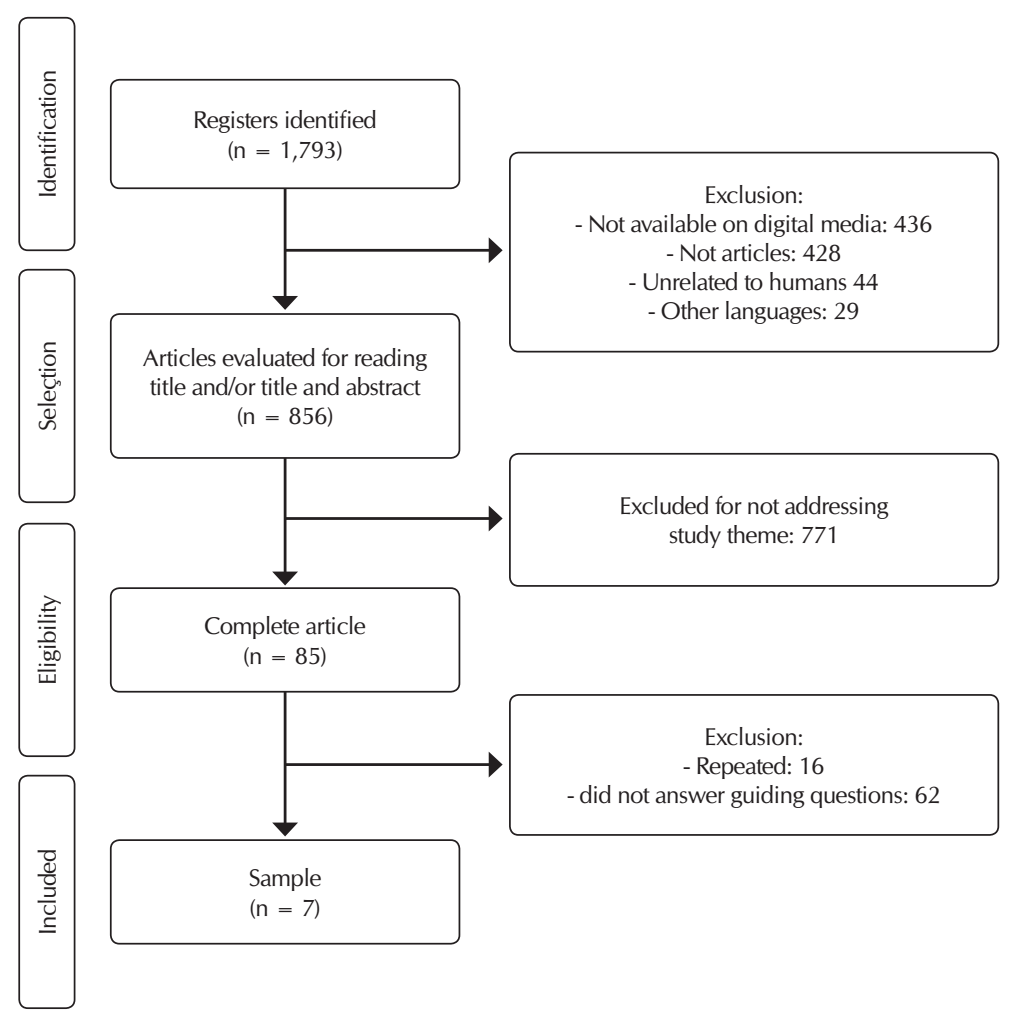

Figure 1 - PRISMA flow diagram for the search and selection process of articles for review

The choice of books was based on the references used to teach Immunology. Three were selected and these contributed to understanding the elements associated with Ineffective protection, namely: Cellular and Molecular Immunology ${ }^{(12)}$, Kuby
Immunology ${ }^{(13)}$ and The Immune System ${ }^{(14)}$. The articles and books were organized in a framework according to the findings for reference, clinical indicators and etiological factors.

\section{RESULTS}

During the reading of selected material, information that answered the guiding questions was extracted. The results found in the literature pointed to five clinical indicators and three etiological factors for Ineffective protection (see Chart 1).

Analysis of the articles revealed that no study had been developed by nurses and that $57.1 \%$ of articles were published in 2014. Different interpretations were found of the term protection related to childhood cancer: two authors related protection to a positive response of the body after use of specific medications, while the remainder referred to an immune response of the body after vaccination or against infections.

Regarding the level of evidence, three articles were classified as level ( $^{(15,18-19)}$, two as level II ${ }^{(17,20)}$ and two as level III ${ }^{(16,21)}$. No studies located addressed the nursing diagnosis Ineffective protection among children and adolescents with cancer. In relation to the clinical indicators of protection in the context of childhood cancer, analysis of the articles and books identified the following: Injured oral mucosa, Injured gastrointestinal mucosa, insufficient antibody titers, recurrent infections and opportunistic infections.

Chart 1 - Synthesis of the results, Brazil, 2016

\begin{tabular}{|c|c|c|}
\hline Title & Clinical Indicators & Etiological Factors \\
\hline $\begin{array}{l}\text { Protection against chemotherapy induced mucositis by } \\
\text { TGF-b2 in childhood cancer patients: Results from a } \\
\text { randomized cross-over study }{ }^{(15)}\end{array}$ & $\begin{array}{l}\text { Injured oral mucosa, Injured } \\
\text { gastrointestinal mucosa }\end{array}$ & $\begin{array}{l}\text { Side effects of treatment (chemotherapy } \\
\text { and radiotherapy) }\end{array}$ \\
\hline $\begin{array}{l}\text { Assessment of hepatitis B immunization status after } \\
\text { antineoplastic therapy in children with cancer }{ }^{(16)}\end{array}$ & Insufficient antibody titers & $\begin{array}{l}\text { Side effects of treatment (chemotherapy), } \\
\text { missed routine vaccinations }\end{array}$ \\
\hline $\begin{array}{l}\text { A prospective study of chemotherapy immunologic effects } \\
\text { and predictors of humoral influenza vaccine responses in a } \\
\text { pediatric oncology cohort }{ }^{(17)}\end{array}$ & Insufficient antibody titers & $\begin{array}{l}\text { Side effects of treatment (chemotherapy), } \\
\text { Missed routine vaccinations }\end{array}$ \\
\hline $\begin{array}{l}\text { Interventions for preventing oral mucositis for patients with } \\
\text { cancer receiving treatment }{ }^{(18)}\end{array}$ & $\begin{array}{l}\text { Injured oral mucosa, Injured } \\
\text { gastrointestinal mucosa }\end{array}$ & $\begin{array}{l}\text { Side effects of treatment (chemotherapy } \\
\text { and radiotherapy) }\end{array}$ \\
\hline $\begin{array}{l}\text { Vaccines for prophylaxis of viral infections in patients with } \\
\text { hematological malignancies }{ }^{(19)}\end{array}$ & Insufficient antibody titers & $\begin{array}{l}\text { Side effects of treatment (chemotherapy), } \\
\text { missed routine vaccinations }\end{array}$ \\
\hline $\begin{array}{l}\text { Immune response after influenza vaccination in children } \\
\text { with cancer }{ }^{(20)}\end{array}$ & Insufficient antibody titers & $\begin{array}{l}\text { Side effects of treatment (chemotherapy), } \\
\text { missed routine vaccinations }\end{array}$ \\
\hline $\begin{array}{l}\text { Differential loss of humoral immunity against measles, } \\
\text { mumps, rubella and varicella-zoster virus in children } \\
\text { treated for cancer }{ }^{(21)}\end{array}$ & Insufficient antibody titers & $\begin{array}{l}\text { Side effects of treatment (chemotherapy), } \\
\text { missed routine vaccinations }\end{array}$ \\
\hline $\begin{array}{l}\text { Cellular and Molecular Immunology } y^{(12)} ; \text { Kuby } \\
\text { Immunology }{ }^{(13)} \text {; The Immune System }{ }^{(14)} \text {. }\end{array}$ & $\begin{array}{l}\text { Recurrent infections; } \\
\text { Opportunist infections }\end{array}$ & $\begin{array}{l}\text { Secondary Immunodeficiencies (cancer, } \\
\text { immunosuppressive treatment) }\end{array}$ \\
\hline
\end{tabular}


The etiological factors of Ineffective protection in children and adolescents with cancer identified in the articles were: side effects of treatment (chemotherapy and radiotherapy), absence of routine vaccines and secondary immunodeficiencies.

\section{DISCUSSION}

The results of this research show that most of the articles were published in 2014, which could mean a growing interest in the subject in view of the increased incidence of childhood cancer. It is underscored that in Brazil 2016, there were an estimated 12,600 new cases of cancer in children and adolescents. The Southeastern and Northeastern regions presented a higher estimated number of cases when compared to the rest of the country ${ }^{(2)}$.

Different interpretations of the term protection related to childhood cancer were found, and no study was located that addressed the nursing diagnosis Ineffective protection among children and adolescents with cancer-denoting a lack of research in this area. It is underscored that protection refers to a term that is difficult to characterize. In nursing, protection is referred to as the fifth basic need identified in the physiological mode of Roy Adaptation Model ${ }^{(22)}$. This theory focuses on the individual and his relationship with the environment, considering the mutual influences between them. The "protection" component is an important adaptation process because it is through the process of life defense that the integrity of the body is maintained.

NANDA-I appears to use a broader meaning for protection, bearing in mind the definition of nursing diagnosis ineffective protection: "decreased ability to protect oneself against internal or external threats, such as illness or injury" ${ }^{\prime(8)}$. This definition presents broad terms, such as internal or external threats, that make it difficult to understand the diagnosis and characteristics that aid in its identification.

However, when analyzing nursing studies that identified this diagnosis in different populations, we can see an association between the presence of the diagnosis and impaired immunity. This fact is evidenced by the defining characteristics and / or related factors used for inference of the diagnosis in the studies by Canero, Carvalho and Galdeano ${ }^{(23)}$, Silva et al. ${ }^{(24)}$ and Neves et al. ${ }^{(25)}$.

In relation to the clinical indicators of protection in the context of childhood cancer after analysis of the articles and books we identified: Injured oral mucosa, Injured gastrointestinal mucosa, insufficient antibody titers, recurrent infections and opportunistic infections.

On comparing these results with the defining characteristics proposed by NANDA-I, it was observed that three of the five identified in this review may be included in the impaired immunity indicator, presented by said taxonomy. These indicators are: Injured gastrointestinal mucosa, Injured oral mucosa and insufficient antibody titers.

Impaired immunity is known to be related to a decrease or failure in the performance of the body's defense function against invading agents ${ }^{(12)}$, including therefore inadequate innate immune or adaptive immune responses. The cells of the hematopoietic system divide rapidly and are highly vulnerable to application of chemotherapeutic agents. When suppressed by drugs, the bone marrow is unable to replenish circulating blood elements, thereby decreasing the number of leukocytes (leukopenia), erythrocytes (anemia) and platelets (thrombocytopenia) ${ }^{(26)}$.

Suppression of the immune system in cancer patients renders them vulnerable to infections, such as those that can be prevented by vaccines. For example, Karaman et al. ${ }^{(16)}$, when evaluating the pre-treatment immunization status of patients against hepatitis $\mathrm{B}$ virus infection, identified a reduction of anti-HBs antibody titer to below the protection level in $33 \%$ of patients with positive antibodies prior to treatment.

Another study that analyzed the loss of protective immunity (immunity at diagnosis and immunity after treatment completion) against preventable diseases in children treated for malignant disease has shown that a significant number of these lose humoral immunity against measles, mumps, rubella and varicella after chemotherapy ${ }^{(21)}$. This contextualizes the clinical indicator insufficient antibody titer, demonstrating that the protection afforded by vaccines may be affected following the application of antineoplastic therapy, thereby exposing children and adolescents to diseases that should not occur after immunization.

In addition, nursing assessment should focus on the recognition of clinical indicators that demonstrate an increased risk for the patient. Injured oral mucosa, for example, was found in this review to be an indicator of impairment in the individual's protection of self, as it is an innate component in human immunity.

Mucositis, a common side effect of treatment for cancer, manifests as inflammation and ulceration of any part of the oral and gastrointestinal mucosa, compromising the alimentary canal ${ }^{(27)}$. Both chemotherapy and radiotherapy generate chemical substances that lead to cellular destruction in the mucosa of the epithelium, connective tissue and blood vessels of the oral cavity, resulting in ulceration and compromised oral tissues ${ }^{(26)}$.

An injury to the oral mucosa represents a means of entry for infectious agents and consequent susceptibility to infection. At this point, it is emphasized that poor oral hygiene, existing dental disease, impaired nutritional status, among other factors involved, may contribute to the morbidity associated with this condition ${ }^{(26)}$.

Another clinical indicator found refers to the loss of intestinal integrity, which predisposes to bacterial translocation and can lead to severe infections in the immunosuppressed patient. These side effects may lead to a reduction in chemotherapy intensity, compromising treatment efficacy ${ }^{(15)}$.

Besides the above mentioned aspects, it is pertinent that the skin and mucosa are the first barriers that the pathogen encounters when trying to reach the individual. Loss of skin integrity represents a port of entry for the invasion of microorganisms.

Another important clinical indicator refers to recurrent infections, which are related to the installation of infectious processes in a repetitive manner. According to Abbas ${ }^{(12)}$, this is the main consequence of impaired immunity. The nature of the infection depends on the defective immune system component, i.e. a deficiency of humoral immunity results in increased susceptibility to infections with pyogenic bacteria, whereas a deficiency in cellular immunity leads to infections with viruses and other intracellular microorganisms ${ }^{(12)}$.

The causes of recurrent infections can range from intrinsic anomalies in the immune system (primary immunodeficiencies) 
to secondary causes, including viral infections; malignancies; metabolic disease; medications (immunosuppressive agents, immunomodulatory agents, and cytotoxic drugs); iatrogenics; surgery, including the removal of immunologically relevant organs (thymus and spleen); and undergoing transplantation ${ }^{(13)}$.

Regarding the indicator opportunistic infections, this term is related to the establishment of an infectious process caused by microorganisms that healthy individuals can tolerate without consequences, but which cause diseases in those with impaired immune function ${ }^{(12)}$. The literature highlights that the most common opportunistic microorganisms are: Candida spp, Mycobacterium, Aspergillus spp., Pneumocystiscarinii, herpes simplex virus, and Cryptococcus neoformans ${ }^{(28)}$.

The etiological factors of Ineffective protection in children and adolescents with cancer identified in the articles were: side effects from treatment (chemotherapy and radiotherapy), missing routine vaccines and secondary immunodeficiencies. When comparing with the related factors of nursing diagnosis Ineffective protection present in NANDA-I (2015-2017), we realized that secondary immunodeficiencies and side effects from treatment (chemotherapy and radiotherapy) coincide. This taxonomy brings immunological disorders as a related factor, which includes the secondary immunodeficiencies ${ }^{(8)}$.

Regarding side effects from treatment (chemotherapy and radiotherapy), the main effects are alterations in cell production by the bone marrow ${ }^{(18)}$. Chemical agents can inhibit lymphocyte proliferation and their specificity for the immune response. These drugs interfere with DNA synthesis, arresting the cell cycle and inducing apoptosis. They are capable of inhibiting the proliferation of T and B lymphocytes and, consequently, any new immune responses. Depending on the dose applied, they inhibit cellular and antibody responses that have been previously sensitized. Therefore, the main limitation of these agents is the damage to hematopoietic and non-hematopoietic cells, with the development of cytopenias and deterioration of the skin and gastrointestinal mucosa. These cytopenias contribute to the state of secondary immunodeficiency and susceptibility to infections ${ }^{(29)}$.

Secondary immunodeficiencies, another etiological factor found in the review, refer to the negative impact that some environmental factors (immunosuppressive drugs, for example) can cause in the immune system ${ }^{(14)}$. Chinen and Shearer ${ }^{(29)}$ cite that this type of deficiency in the immunity is manifested by increasing the frequency of common infections or unusual complications of these infections, as well as the occurrence of opportunistic infections.

Another etiological factor identified in the articles was missing vaccines. It is known that the expected response after vaccine application is a specific immunity to a particular infection causing agent. However, common childhood infections can be dangerous, and children should not be immunized against such diseases (measles, mumps, rubella, and polio) when the immune system is depressed, since attenuated virusbased vaccines can cause severe infection ${ }^{(30)}$.

It is noted that there are clinical indicators and etiological factors that may be important to identify the diagnosis Ineffective protection in adolescents with cancer beyond those cited by NANDA-I. Therefore, it is suggested to carry out a future clinical validation study, to refine the diagnosis in question, including the elements identified in this review.

\section{Study limitations}

The limitations of the study were the definition of inclusion criteria and keywords, which may have restricted the identification of studies important for the review. In addition, the number of databases included for the search of the articles, such that it is important to continue research in other databases to complement the results of this study.

\section{Contribution to nursing, health or public policy}

It is important to understand the aspects associated with a decreased protection capacity of the individual, especially in the context of childhood cancer. Awareness of the clinical indicators that these individuals may present, as well as the possible causes for this impairment may help the nurse to identify such alteration earlier.

\section{CONCLUSION}

This study found that changes in the ability to protect against possible diseases or injuries have been poorly addressed, especially when referring to a nursing phenomenon. This indicates the need to develop nursing research that addresses this question. In short, various interpretations of the term protection related to childhood cancer were found: positive response of the organism after use of specific medications; and immune response of the body after vaccination or against infections.

In addition, this study allowed the identification of five clinical indicators of a change in the protection of the individual: Injured oral mucosa, Injured gastrointestinal mucosa, insufficient antibody titers, recurrent infections and opportunistic infections. Regarding the factors that may lead to a decrease in the protection capacity, we found: side effects from treatment (chemotherapy and radiotherapy), missing routine vaccines and secondary immunodeficiencies. It is underscored that here are clinical indicators and etiological factors that may be important to identify an alteration in the protection of adolescents with cancer that are not mentioned in NANDA-I.

\section{REFERENCES}

1. Siegel R, Miller KD, Jemal A. Cancer Statistics. CA Cancer J Clin[Internet]. 2016 [cited 2016 Jan 9];66:7-30. Available from: http:// onlinelibrary.wiley.com/doi/10.3322/caac.21332/full

2. Brasil. Ministério da Saúde. Instituto Nacional de Câncer. Estimativa 2016: incidência de câncer no Brasil[Internet]. Rio de Janeiro: INCA, 2015[cited 2016 Mar 30]. Available from: http://www.inca.gov.br/wcm/dncc/2015/estimativa-2016.asp 
3. Brasil. Ministério da Saúde. Instituto Nacional do Câncer. Tipos de câncer infantil[Internet]. Rio de Janeiro: INCA, 2012[cited 2016 Mar 30]. Available from: http://www2.inca.gov.br/wps/wcm/connect/tiposdecancer/site/home/infantil

4. Hockenberry MJ, Wilson D. Wong: fundamentos de enfermagem pediátrica. 8 ed. Rio de Janeiro: Elsevier; 2011.

5. UNICEF. United Nations Children's Fund. Situação Mundial da Infância, 2011[Internet]. New York, NY: Hatteras Press, 2011 [cited 2016 Mar 30]. Available from: http://www.unicef.org/sowc2011/pdfs/SOWC-2011-Main Report_EN_02092011.pdf

6. Johnson SB, Blum RW, Giedd JN. Adolescent Maturity and the Brain: The promise and pitfalls of neuroscience research in adolescent health policy. J Adolesc Health[Internet]. 2009 [cited 2015 Jul 22];45(3):216-21. Available from: https://www.ncbi. nlm.nih.gov/pmc/articles/PMC2892678/

7. Brasil. Ministério da Saúde. Atenção psicossocial a crianças e adolescentes no SUS: tecendo redes para garantir direitos[Internet]. Brasília: Ministério da Saúde; 2014[cited 2016 Mar 30]. Available from: http://www.crianca.mppr.mp.br/arquivos/File/publi/ cnmp/atencao_psicossocial_criancas_adolescentes_sus.pdf

8. Herdman TH, Kamitsuru S (Eds.), NANDA International Nursing Diagnoses: definitions \& classification. 2015-2017, WileyBlackwell: Oxford; 2014.

9. Mendes KDS, Silveira RCCP, Galvão CM. Revisão integrativa: método de pesquisa para a incorporação de evidências na saúde e na enfermagem. Texto Contexto Enferm [Internet]. 2008 [cited 2015 Jan 7];17(4):758-64. Available from: http://dx.doi.org/10.1590/ S0104-07072008000400018

10. Herdman TH. Diagnósticos de enfermagem da NANDA: definições e classificação 2012-2014. Porto Alegre: Artmed, 2013.

11. Howick J, Chalmers I, Glasziou P, Greenhalgh T, Heneghan C, Liberati A, et al. OCEBM Levels of Evidence Working Group. "The Oxford Levels of Evidence 2". Oxford Centre for Evidence-Based Medicine The Oxford 2011 Levels of Evidence [Internet] 2011[cited 2017 Feb 1]. Available from: http://www.cebm.net/ocebm-levels-of-evidence

12. Abbas AK, Lichtman AH. Pillai S. Imunologia Celular e Molecular. 6 ed. Rio de Janeiro: Elsevier, 2008.

13. Kindt TJ, Goldsby RA, Osborne BA. Imunologia de Kuby. Silva AC (Trad.). 6 ed. Porto Alegre: Artmed, 2008.

14. Parham P. The Immune System. 3 ed. London: Garland Science, 2009.

15. Koning BAE, Philipsen-Geerling B, Hoijer M, Hählen K, Büller HA, Pieters R. Protection against chemotherapy induced mucositisby tgf-b2 in childhood cancer patients: results from a randomized cross-over study. Pediatr Blood Cancer[Internet]. 2007 [cited 2015 Jan 13]48:532-9. Available from: http://onlinelibrary.wiley.com/wol1/doi/10.1002/pbc.20910/full

16. Karaman S, Vural S, Yildirmak Y, Urganci N, Usta M. Assessment of hepatitis B immunization status after antineoplastic therapy in children with cancer. Ann Saudi Med[Internet]. 2011 [cited 2015 Jan 15]31(6):573-6. Available from: https://www.ncbi.nlm. nih.gov/pmc/articles/PMC3221126/

17. Kersun LS, Reilly A, Coffin SE, Boyer J, PrakETL, McDonald K, Hou X, et al. A prospective study of chemotherapy immunologic effects and predictors of humoral influenza vaccine responses in a pediatric oncology cohort. Influenza Other Respir Viruses[Internet]. 2012 [cited 2015 Jan 13]7(6):1158-67. Available from: https://www.ncbi.nlm.nih.gov/pmc/articles/PMC4634289/

18. Worthington HV, Clarkson JE, Bryan G, Furness S, Glenny AM, Littlewood Anne, et al. Interventions for preventing oral mucositis for patients with cancer receiving treatment. Cochrane Database of Systematic Reviews. In: The Cochrane Library, Issue 12, 2014, Art. No. CD000978. DOI: 10.1002/14651858.CD000978.pub1

19. Cheuk DK, Chiang AK, Lee TL, Chan GC, Ha SY. Vaccines for prophylaxis of viral infections in patients with hematological malignancies. Cochrane Database of Syst Rev. In: The Cochrane Library, Issue 12, 2014, Art. No. CD006505. DOI: 10.1002/14651858.CD006505.pub3

20. Matsuzaki A, Suminoe A, Koga Y, Kinukawa N, Kusuhara K, Hara T, et al. Immune Response After Influenza Vaccination in Children With Cancer. Pediatr Blood Cancer[Internet]. 2005 [cited 2015 Feb 2]45:831-7. Available from: http://onlinelibrary. wiley.com/wol1/doi/10.1002/pbc.20470/full

21. Bochennek K, Allwinn R, Langer R, Becker M, Keppler OT, Klingebiel T, et al. Differential loss of humoral immunity against measles, mumps, rubella and varicella-zoster virus in children treated for cancer. Vaccine[Internet]. 2014[cited 2015 Jan 28]32(27):3357-61. Available from: https://www.ncbi.nlm.nih.gov/pubmed/24793952

22. Roy C. The Roy Adaptation Model. New Jersey. 3 ed. Upper Saddle River, NJ: Prentice Hall Health, 2009.

23. Canero TR, Carvalho R, Galdeano LE. Diagnósticos de enfermagem para o pós-operatório imediato de pacientes submetidos a transplante hepático. Einstein. 2004;2(2):100-4.

24. Silva MR, Bettencourt ARC, Diccini S, Belasco A, Barbosa DA. Diagnósticos de enfermagem em portadores da Síndrome da Imunodeficiência adquirida. Rev Bras Enferm[Internet]. 2009[cited 2015 Feb 7]62(1):92-9. Available from: http://www.scielo.br/ pdf/reben/v62n1/14.pdf

25. Neves JF, Paixão FRC, Lima TC, Ceolim MF. Nursing diagnoses of patients admitted for Infectious Diseases. Acta Paul Enferm[Internet]. 2010[cited 2015 Feb 6]23(6):818-23. Available from: http://www.scielo.br/pdf/ape/v23n6/en_16.pdf

26. Smeltzer CS, Bare BG, Hinkle JL, Cheever KH. Brunner \& Suddarth: tratado de enfermagem médico-cirúrgica. 11 ed. Rio de Janeiro: Editora Guanabara/Koogan, 2009.

27. McGuire DB. Mucosal Tissue Injury in Cancer Therapy. Cancer Practice[Internet]. 2002 [cited 2015 Jan 25]10:179-91. Available 
from: https://www.ncbi.nlm.nih.gov/pubmed/12100102

28. Klastersky J, Aoun M. Opportunistic infections in patients with cancer. Ann Oncol[Internet]. 2004 [cited 2015 Jan 30]15(4):32935. Available from: http://annonc.oxfordjournals.org/content/15/suppl_4/iv329.full.pdf

29. Chinen J, Shearer WT. Secondary immunodeficiencies, including HIV infection. J Allergy Clin Immunol[Internet]. 2010[cited 2015 Feb 4];125(2). Available from: https://www.ncbi.nlm.nih.gov/pubmed/20042227

30. Bryant R. A criança com disfunção hematológica ou imunológica. In: Hockenberry, M. J.; Wilson, D. Wong: fundamentos de enfermagem pediátrica. 8 ed. Rio de Janeiro: Elsevier, 2011. 